\title{
Ocular allergy latin american consensus
}

\section{Consenso latino americano de alergia ocular}

Myrna Serapião dos Santos ${ }^{1}$, Milton Ruiz Alves², Denise de Freitas ${ }^{3}$, Luciene Barbosa de Sousa ${ }^{4}$, Ricardo Wainsztein ${ }^{5}$, Sérgio Kandelman ${ }^{6}$, Mauricio Lozano ${ }^{7}$, Francisco Beltrán ${ }^{8}$, Oscar Baça Lozada ${ }^{9}$, Concepción Santacruz ${ }^{10}$, Giovanni Guzzo ${ }^{11}$, Carlos Alberto Zaccarelli Filho ${ }^{12}$, José Álvaro Pereira Gomes ${ }^{13}$

\section{ABSTRACT}

Purpose: To establish current definition, classification and staging, and to develop diagnosis and treatment recommendations for ocular allergy, by using Delphi approach.

Methods: Ten Latin American experts on ocular allergy participated in a 4-round Delphi panel approach. Four surveys were constructed and answered by panelists. A two-thirds majority was defined as consensus. Definition, classification, staging and diagnosis and treatment recommendations were the main outcomes.

Results: "Ocular allergy" was proposed as the general term to describe ocular allergic diseases. Consensus regarding classification was not reached. Signs and symptoms were considered extremely important for the diagnosis. It was consensus that a staging system should be proposed based on the disease severity. Environmental control, avoidance of allergens and the use of artificial tears were recommended as first line treatment. The secondary treatment should include topical anti-histamines, mast cell stabilizers and multi actions drugs. Topical non-steroidal anti-inflammatory and vasoconstrictors were not recommended. Topical corticosteroids were recommended as third line of treatment for the most severe keratoconjunctivitis. Consensus was not reached regarding the use of systemic corticosteroids or immunosuppressant. Surgical approach and unconventional treatments were not recommended as routine. Conclusion: The task of creating guidelines for ocular allergies showed to be very complex. Many controversial topics remain unsolved. A larger consensus including experts from different groups around the world may be needed to further improve the current recommendations for several aspects of ocular allergy.

Keywords: Questionnaires; Consensus; Conjunctivis, allergic; Keratoconjunctivitis; Adrenal cortex hormones; Immunosuppressive agents

\section{RESUMO}

Objetivo: Estabelecer a definição, classificação e estadiamento e desenvolver recomendações para o diagnóstico e tratamento da alergia ocular, usando o método Delphi de consenso.

Métodos: Dez especialistas em alergia ocular da América Latina participaram do painel. Quatro rodadas de questionários foram respondidas pelos painelistas. Consenso foi definido quando houve 2/3 ou mais de concordância. Os aspectos principais avaliados foram: definição, classificação, estadiamento e recomendações para diagnóstico e tratamento da alergia ocular.

Resultados: "Alergia Ocular" foi proposto como termo geral para descrever as doenças alérgicas oculares. Consenso sobre classificação não foiatingido. Sinais e sintomas foram considerados extremamente importantes para o diagnóstico. Consenso foi atingido sobreanecessidade deseestabelecer um sistema deestadiamento baseado na gravidade da doença. Controle ambiental e de exposição a alérgenos e o uso de lágrimas artificiais foram considerados tratamento de primeira linha e o uso tópico de anti-histamínicos, estabilizadores de membranas de mastócitos e drogas de ação múltipla, como tratamento de segunda linha. Anti-inflamatórios não hormonais tópicos e vasoconstrictores não foram recomendados. Corticosteroides tópicos foram estabelecidos como terceira linha de tratamento para casos graves de ceratoconjuntivite. Consenso não foi obtido em relação ao uso sistêmico de corticosteróides e imunossupressores. Abordagem cirúrgicae tratamentos não convencionais não foram recomendados de rotina.

Conclusão: O desafio de criar recomendações para diversos aspectos da alergia ocular mostrou-se muito complexo, muitos deles permanencendo ainda controversos. Consensos mais amplos podem ser necessários para melhorar as recomendações atuais referentes a importantes aspectos da alergia ocular.

Descritores: Questionários; Consenso; Conjuntivite alérgica; Ceratoconjuntivite; Corticosteroides: Imunossupressores
Submitted for publication: May 12,2011

Accepted for publication: December 8, 2011

Study carried out at the Primeira parte (Questionários): online. Segunda parte (Meeting): Orlando Miami, USA. Terceira Parte (Análise Estatística): São Paulo (SP), Brazil.

Physician, Setor de Córnea e Doenças Externas, Universidade Federal de São Paulo - UNIFESP Centro Avançado de Superfície Ocular - CASO - Instituto da Visão - UNIFESP - São Paulo (SP), Brazil.

Physician, Seção Doenças Externas e Córnea do Hospital das Clínicas, Faculdade de Medicina, Universidade de São Paulo - FMUSP - São Paulo (SP), Brazil.

Physician, Departamento de Oftalmologia, Universidade Federal de São Paulo - UNIFESP - São Paulo (SP), Brazil.

Physician, Departamento de Oftalmologia do Hospital de Olhos de Sorocaba, Sorocaba (SP), Brazil. Physician, Instituto de La Visión, Universidad de Buenos Aires, Buenos Aires, Argentina.

Physician, Clínica Skopus, Rio de Janeiro (RJ), Brazil.

Physician, Departamento de Oftalmologia Pediatrica y Estrabismo, Jefe de Educación Médica Fundación Oftalmologica Nacional, Profesor Asociado de Oftalmologia - Universidad del Rosario, Fundación Oftalmologic
Rosario, Argentina.

8 Posario, Argentina. Physician, Servicio de Córnea y Cirugía Refractiva. Hospital Dr. Luis Sánchez Bulnes e
Lomas Altas, Asociación para evitar la ceguera en Mexico. I.A.P. (APEC), Mexico, D. F.

9 Physician, Servicio de Córnea, Fundación Hospital Nuestra Señora de la Luz Mexico, DF.

Physician, Servicio de Córnea, Instituto de Oftalmología, Fundación Conde de Valenciana I.A.P. Mexico, DF.

11 Physician, Clinical Operations Manager, Intrials Clinical Research, São Paulo (SP), Brazil.

12 Physician, BDM \& Clinical Research Associate, Intrials Clinical Research. São Paulo (SP), Brazil.

13 Physician, Setor de Córnea e Doenças Externas, Instituto da Visão,Universidade Federal de São

Paulo - UNIFESP - São Paulo (SP), Brazil.
Funding: No specific financial support was available for this study.

Disclosure of potential conflicts of interest: M.S.Santos, Recipient (Allergan); M.R.Alves, Recipien (Allergan); D.de Freitas, Recipient (Allergan); L.B.Sousa, Recipient (Allergan); R.Wainsztein Recipient (Allergan); S. Kandelman, Recipient (Allergan); M.Lozano, Recipient (Allergan); F.Beltrán Recipient(Allergan);O.B.Lozada, Recipient(Allergan); C Santacruz, Recipient(Allergan); G.Guzzo, Recipient (Allergan); C.A.Zaccarelli Filho, Recipient (Allergan); J.A.P.Gomes, Recipient (Allergan)

Correspondence address: Myrna Serapião dos Santos. Rua José de Guimarães, 373 - Apto. 1201 - São Paulo (SP) - 04026-090 - Brazil - E-mail: myrna_serapiao@uol.com.br 


\section{INTRODUCTION}

Allergic conjunctivitis is a term used to describe a highly prevalent group of heterogeneous diseases of the ocular surface affecting $20 \%$ of the population worldwide ${ }^{(1)}$. It is usually associated with type I hypersensitivity reaction and the spectrum of clinical expression varies according to individual cases ${ }^{(1-2)}$. Seasonal allergic conjunctivitis (SAC), perennial allergic conjunctivitis (PAC), vernal keratoconjunctivitis (VKC) and atopic keratoconjunctivitis (AKC) are the ocular allergic disorders more frequently classified under the denomination of "allergic conjunctivitis"(3). In spite of their different pathophysiological features, some authors also include other types of allergy-related reactions, as giant papillary conjunctivitis (GPC), as part of this group of disease ${ }^{(4)}$.

Clinical evaluation criteria are essential not only for diagnosis, but also for objective assessment in clinical trials and for clinical studies on etiological aspects of ocular allergic diseases ${ }^{(5)}$. However, there have been no internationally established criteria for clinical evaluation and classification of the severity of ocular allergic diseases.

In the past, the treatment of ocular allergy focused on symptomatic relief. More recently, the understanding of the mechanisms involved in the pathophysiology of this group of diseases has provided new therapeutic strategies and guidelines ${ }^{(4)}$.

The pharmacologic management of the ocular allergy has been expanded to specifically address not only the symptomatic relief, but also signs and symptoms of inflammation associated with the disease ${ }^{(6)}$.

Despite the high prevalence, its definition, a standard classification and staging as well as the guidelines to diagnosis and treatment are not globally accepted. In situations where unanimity of opinions does not exist because of a lack of or contradictory scientific evidences, consensus methods can be useful. A panel of experts may be an appropriated method to obtain a consensus based on current knowledge $\mathrm{e}^{(7-8)}$

The Delphi panel technique was first proposed in 1946 by RAND Corporation as a method to collect informations from experts and to predict future technological capabilities ${ }^{(9)}$. This tool has been expanded to health research to create algorithms of treatment ${ }^{(10-13)}$. In ophthalmology, it was recently used for establishing a Consensus on dry eye ${ }^{(8)}$.

In this study, we proposed to establish a consensus on definition, classification, staging and diagnosis and treatment recommendations for ocular allergy, obtained from a panel of Latin American experts by using the Delphi approach.

\section{METHODS}

The study was designed to acquire knowledge on Ocular Allergy from Latin American ophthalmologists and the Delphi method was chosen as consensus method.

\section{Delphi Panel}

\section{Panelists selection}

For the selection of the panelists group, some important characteristics were considered: a) panelists should be diverse in terms of background; b) representative of the target population; and c) to have qualification in the area of interest. All the experts invited met every criteria suggested for the panel selection. Based on these three requirements, four inclusion criteria were considered for the selection of panelists:

1. To be willing to answer sets of questionnaires that were sent in rounds 1 and 2 .

2. To be willing to participate on a two day meeting in Orlando US (round 4).

3. To work as an active licensed ophthalmologist in a Latin American country.

4. To have both local and regional acknowledgement as a cornea expert confirmed by the actual affliation/position, number of publications and participation as a speaker in local and international scientific meetings of the subspecialty.

Ten panelists were selected from 4 different Latin American countries to compose the panel (Wainsztein R - Argentina; Alves MR, Freitas D, Sousa LB, Santos MS, and Kandelman S - Brazil; Lozano M Colombia; Beltran F, Baca O, and Santacruz C - Mexico).

\section{Contract Research Organization (CRO)}

A CRO (Intrials Pesquisa Clínica, São Paulo, Brazil) was selected to coordinate the deployment of questionnaires, and to work as a statistical and Delphi method consultant.

\section{Preparation of Questionnaires}

All questionnaires were based on clinical experience and practice on the literature on ocular allergy. Rounds of questionnaires were generated and sent to panelists according to the reached consensus.

The questionnaires were posted on an access-controlled website.

\section{Determination of CONSENSUS AND analysis OF DATA}

In order to assure a consistent and robust method for the determination of consensus, a different method of analysis was used for each kind of question. All statistics were calculated on the BioStat 3.0 (Sociedade Civil Mamirauá, Brazil).

\section{FACE-TO-FACE MEETING}

The panelists had a meeting where the preliminary results of the previous rounds were presented and discussed. This moment was formatted also as a round with personal interaction among the participants.

\section{RESULTS}

\section{Definition of ocular allergic diseases}

The majority of panelists (>66.67\%) agreed that the most appropriated term to describe the allergic diseases of the ocular surface is "ocular allergy".

There was also consensus regarding the definition of ocular allergy. According to the panelists, ocular allergy should be defined as "an inflammatory disease of the ocular surface, frequently recurrent, whose basic pathophysiological mechanism is the type I hypersensitivity, associated or not with other types of hypersensitivity reactions".

\section{Classification of ocular allergic diseases}

Initially, when panelists were surveyed on sub-types of ocular allergic diseases that should be included in the classification of ocular allergy, consensus was reached that the following sub-types should be included: Seasonal conjunctivitis (SAC), Perennial conjunctivitis (PAC), Vernal keratoconjunctivitis (VKC), Atopic keratoconjunctivitis (AKC), and Contact blepharoconjunctivitis (CBC).

At the face-to-face meeting, considering the high level of controversies found in the literature, panelists discussed this topic. It was decided to repeat this question in a $4^{\text {th }}$ round. Even so, a consensus was not reached. Half of panelists (5/10) classified the following subtypes under the term "ocular allergy": SAC, PAC, VKC, AKC and, in spite of having different mechanisms, GPC and CBC.

In another topic regarding classification, more than $66.67 \%$ of panelists also agreed that ocular allergic diseases should be classified, in terms of duration, in acute and chronic and recurrent forms.

\section{Diagnosis of oCUlar allergic diseases/DIFFERENTIAL DIAGNOSIS}

The panel members agreed that anamnesis, slit-lamp examination and fluorescein staining are important diagnostic measures 
to detect the ocular surface allergic disease $\left(X^{2}{ }_{\text {calc }}<X^{2}{ }_{0.05}\right)$. There was also consensus about the importance of signs and symptoms to the diagnosis (Table 1; Table 2).

Dysfunctional tear syndrome and blepharitis were indicated by panelists (>66.67\%) as the most important conditions that should be considered in the differential diagnosis of ocular allergies.

\section{Staging of ocular ALlergic diseases}

Regarding the importance to establish a staging, the majority agreed in some degree of importance (>66.67\%), especially to follow patients and to determine algorithms of treatment. They also recommended that it should be made based on levels of severity, according to the signs of the disease $\left(X_{\text {calc }}<X^{2}{ }_{0.05}\right)$.

At the face-to-face meeting, the panel members tried to establish an appropriated staging based on levels of severity. However, they did not reach consensus regarding this topic. Therefore, a round 4 was generated to validate the suggestions made during the meeting. The analysis of the fourth round showed no consensus on the choice of the best staging criteria for Ocular Allergy. Merely illustrative, table 3 presents the chosen staging by less than half of panelists (4/10).

\section{TREATMENT GUIDELINES}

The panelists were questioned on the following goals for the ocular allergy therapy: control of signs and symptoms and tolerability to medications. The degree of importance agreed among the panelist is presented on table 4.

The panel members (>66.67\%) recommended the environmental control and the need to avoid contact with known allergens as primary interventions that should be used as part of first-line step for the treatment of ocular allergy.

Table 1. Most important signs for ocular allergy diagnosis*

\begin{tabular}{lc}
\hline Signs & Level of importance \\
\hline Papillary hypertrophy of superior tarsal & Extremely important \\
Diffuse conjunctival papillary hypertrophy & Extremely important \\
Shield ulcer & Extremely important \\
Limbal edema & Extremely important \\
\hline
\end{tabular}

* $=$ Cronbach alpha $=0.7$

Table 2. Most important symptoms for ocular allergy diagnosis**

\begin{tabular}{lc}
\hline Symptoms & Level of importance \\
\hline Itching & Extremely important \\
Tearing & Very important \\
Mucous discharge & Very important \\
Edema & Very important \\
\hline
\end{tabular}

${ }^{* *}=$ Cronbach alpha $=0.8$

\section{Artificial tears}

The majority of panelists (>66.67\%) answered that they always use topical lubricants for treating ocular allergy. Three remnant panelists indicated topical lubricants only for some chronic cases and for acute crisis. When asked about for how long, most of them (9 of 10) agreed that they should be used indefinitely. It was also consensus that preservative free artificial tears should be prescribed (>66.67\%).

\section{Anti-histamines}

The majority of panel members (80\%) agreed that topical antihistamines are indicated only in the treatment of acute cases of ocular allergy and for a short period (less than 4 weeks) of time.

\section{Mast cells stabilizers}

Panelists reached consensus during the first round of questions, and at the face-to-face meeting they unanimously agreed (100\%) that topical mast cells stabilizers are extremely important and should be always used in the treatment of ocular allergic patients during an undefined period of time.

\section{Multiple action drugs (MAD)}

When panel members were surveyed on the importance of the use of topical multiple action (anti-histamine, mast cell stabilizer and anti-inflammatory actions) drugs, consensus was reached $(>66.67 \%)$ that they are extremely important for ocular allergy treatment. During the face-to-face meeting, panelists recommend a "once a day use" as being desirable for these drugs.

\section{Topical vasoconstrictor}

The majority of panelists (80\%) did not recommend topical vasoconstrictors for the treatment of ocular allergic patients.

\section{Topical non-steroidal anti-inflammatory drugs (NSAID)}

When panelists were inquired about their opinions regarding the use of topical NSAID in the treatment of ocular allergic patients, $90 \%$ of them agreed that it is not important, thus, they should not be recommended.

\section{Topical corticosteroids}

Even though more than half of panelists ( 6 of 10) agreed on the use of topical corticosteroids as an important choice for treating some chronic cases and acute crises of ocular allergy, no consensus was reached on this issue. However, during the face-to-face meeting, panel members $(<66.67 \%)$ made some recommendations regarding the indications of this class of drugs. Considering the known treatment-related ocular adverse events with the use of topical corticosteroids, the panel agreed that they should not be used as first option treatment in the majority of ocular allergy cases. The panel also recommended the use of "weak topical corticosteroids" for treating specific cases, for a short period of time (less than 2 weeks), always considering the intensity of the acute crisis; and "strong corticosteroids", for treating acute crisis, also during a short period of time (from 2 to 4 weeks).

Table 3. Staging of ocular allergy severity

\begin{tabular}{lllcl}
\hline Grade/Level & \multicolumn{1}{c}{ Papilla } & Conjunctiva & Cornea & Limbus \\
\hline 1 & Micro: $\leq 0,5 \mathrm{~mm}$ & Hyperemia & $(-)$ & $(-)$ \\
2 & Micro: $\leq 0,5 \mathrm{~mm}$ & Hyperemia & Sectorial SPK & Limbitis in 1 quadrant \\
3 & Macro: $\geq 0,5 \mathrm{~mm}-1 \mathrm{~mm}$ & Hyperemia and edema & Diffuse SPK & Limbitis in 2 quadrants \\
4 & Giants: $\geq 1 \mathrm{~mm}$ & Hyperemia, edema and scar & Ulcer & Limbitis in 3 or more quadrants \\
\hline
\end{tabular}

SPK= superficial punctate keratitis 
Table 4. Goals for ocular allergy therapy*

\begin{tabular}{lc}
\hline Symptoms & Level of importance (Likert scale result) \\
\hline Symptoms control & Extremely important \\
Signs improvement & Extremely important \\
Tolerability & Extremely important \\
Quality of life & Extremely important \\
Time of action & Extremely important \\
Cost & Very important \\
Visual acuity improvement & Very important \\
\hline
\end{tabular}

${ }^{*}=$ Cronbach alpha $=0.9$

\section{Topical immunomodulator}

When asked about the need of to use topical immunomodulator for controlling signs and symptoms in ocular allergic patients, $90 \%$ of panelists answered that they never indicated this class of medication.

\section{Systemic corticosteroids \& immunomodulator/immunosuppression}

Regarding the use of systemic treatment with corticosteroids or immunomodulator/immunosuppressant, no consensus was achieved on its use. Half of panelists indicate the use of these medications only for some severe cases of chronic allergic keratoconjunctivitis and the other half of them never use this systemic treatment for any type of ocular allergies.

\section{Surgical treatment}

Consensus was reached on indications of surgical treatment of ocular allergic patients. Eighty percent of panelists did not indicate any kind of surgery for treating ocular allergy. At the face-to-face meeting, panelists made some comments regarding this topic and agreed that surgical treatment may be indicated in very specific cases or in the presence of complications, and that it should be considered as ultimate treatment option for the most severe cases.

\section{Unconventional treatment}

During the face-to-face meeting, panelists discussed on indications of unconventional treatment, such us vaccine, homeopathies and acupuncture. They did not recommend these therapies for ocular allergy therapy.

\section{DISCUSSION}

A variety of scientific methods are used in scientific studies for consensus procedures, as Nominal Group, NIH Consensus Development, and Delphi Panel ${ }^{(12) .}$. From all these, the Delphi Panel method is the most used in health field with more patterns described and standardized ${ }^{(13)}$

There is no general agreement in the literature that defines specific criteria to determine when consensus has been achieved, or the best statistical method to use for responses analysis ${ }^{(10-11)}$. The proposed analytical process performed in this study had the objective to ensure maximum validity of the results in Delphi methodology and improved evidence decisions achieved.

A result obtained from the panel was the recommendation of changing the term "allergic conjunctivitis", commonly used to denominate all ocular allergic disorders, to "ocular allergy". Ocular allergy seems to be a broad and more appropriated term to describe this group of heterogeneous diseases, whose basic mechanism is allergic, including conjunctivitis and keratoconjunctivitis.

Different classifications of the ocular allergic diseases have been proposed in the literature ${ }^{(3,14-16)}$. Recently, the International Ocular Inflammation Society proposed a classification based on the type of immune response, dividing the ocular allergic conditions into 3 groups: IgE-mediated (SAC/PAC), IgE and non IgE-mediated (VKC/AKC) and non lgE-mediated (GPC/CBC) ${ }^{(16)}$.

Panelists discussed on different immunopathogenetic mechanisms involved in the various types of ocular allergies and the wide variety of clinical features of these diseases as well, as important issues that difficult the establishment of an appropriated classification. Although a consensus regarding this topic has not been reached, half of panelists suggested the inclusion of Seasonal and Perennial allergic conjunctivitis, Vernal and Atopic keratoconjunctivitis, Giant papillary conjunctivitis and Contact blepharoconjunctivitis under the term "Ocular allergy".

Consensus was reached on the significance of establishing a staging of ocular allergic diseases based on levels of severity. Such staging would allow appropriated evaluation of progression, the establishment of algorithms of treatment, as well as objective assessment in clinical trials for analysis of treatment efficacy ${ }^{(5)}$.

During the meeting, some general staging applicable to all types of ocular allergy were proposed. However, panelists did not consensually agree on any suggested staging. A possible reason for this is the difficult of effectively evaluating the severity of different diseases together with all of their diverse clinical features. Thus, panelists are in agreement that staging of specific types of ocular allergic diseases are recommended, as those recently published based on severity of signs and symptoms of VKC ${ }^{(17)}$ and $A K C^{(18)}$.

Advances in the understanding of ocular allergic disorders mechanisms have provided foundation for more rational guidelines of treatment of these diseases. The goals of therapy should include not only the control of signs and symptoms, but also improvement of ocular health of patients with ocular allergies $(2,4,6,19)$. Panelists suggested measures including environmental control and avoidance of allergens, which might be achieved by removing allergens source or changing occupational venue, as first line treatment. Another recommendation was the use of artificial tears for all cases of ocular allergies, aiming at either the removal and dilution of allergens or the reestablishment of the tear film, which can be compromised by ocular surface inflammation produced by the allergic response.

The panel recommended that the secondary treatment should include the use of topical anti-histamines, mast cell stabilizers and multi actions drugs, as measures of symptomatic control. Despite some clinical studies showing improvement of symptoms with its use in patients with SAC, topical non-steroidal anti-inflammatory drugs were not recommended ${ }^{(20)}$.

The third line of treatment should be indicated for the most severe cases of keratoconjunctivitis, when topical medications failed in controlling allergic signs and symptoms. Panelists indicated the rational use of topical corticosteroids for treating some chronic cases and acute crises, considering a short time course of treatment and its ocular side effects. Although there are clinical trials showing that topical cyclosporine A might aid in the control of VKC and AKC patients ${ }^{(21-22)}$, most of panelists did not indicate topical immunomodulator as routine to treat ocular allergies. They discussed on the need of high concentrations of the drug and the low tolerability to the available vehicles as limiting factors for its use.

Regarding the surgical approach, panelists in general contraindicated its use for any case of ocular allergy. However, after discussing during the face-to-face meeting, they suggested to consider such treatment in extremely severe cases for treating corneal complications, such as persistent and unresponsive to conventional treatment keratitis and very recurrent shield ulcer. Some publications have reported good results with the surgical removal of giant papillae from superior tarsal conjunctiva associated with several techniques, such as mucous membrane graft, for treating corneal complications in patients with VKC ${ }^{(23-24)}$. However, there is still a lack of evidence-based results that indicate rationality for their use. For 
this same reason, panelists answered that they did not indicate unconventional treatment, such us vaccine, homeopathies and acupuncture for treating ocular allergies.

The task of creating guidelines for ocular allergies showed to be very complex. Thus, a larger consensus including experts from different groups around the world may be needed to further improve many controversial topics, especially an internationally acceptable classification and staging and a more rationale algorithm of treatment for this challenger group of diseases.

\section{REFERENCES}

1. Trocme SD, Karan K. Spectrum of ocular allergy. Curr Opin Allergy Clin Immunol. 2002; 29(5):423-7.

2. Ono SJ, Abelson M B. Allergic conjunctivitis: updates on pathophysiology and prospects for future treatment. J Allerrgy Clin Immunol. 2005;115(1):118-22.

3. Calonge M. Classification of ocular atopic/allergic disorders and conditions: an unsolved problem. Acta Ophthalmol Scand Suppl. 1999;(228):10-3.

4. Bielory L. Ocular allergy guidelines - a practical treatment algorithm. Drugs. 2002;629(11): 1611-34.

5. Uchio E, Kimura R, Migita H, Kozawa M, Kadonosono K. Demographic aspects of allergic disorders and evaluation of new criteria for clinical assessment of ocular allergy. Graefes Arch Clin Exp Ophthalmol. 2008;246(2):291-6.

6. Bielory L. Ocular allergy treatment. Immunol Allergy Clin North Am. 2008;28(1):189-224

7. Behrens A, Doyle JJ, Stern L, Chuck RS, McDonnell PJ, Azar DT, Dua HS, Hom M, Karpecki PM, Laibson PR, Lemp MA, Meisler DM, Del Castillo JM, O'Brien TP, Pflugfelder SC, Rolando M, Schein OD, Seitz B, Tseng SC, van Setten G, Wilson SE, Yiu SC; Dysfunctional tear syndrome study group. Dysfunctional tear syndrome: A Delphi approach to treatment recommendations. Cornea. 2006:25(8):900-7.

8. Serle J, Cantor L, Gross R, Katz J, Mundorf T, Noecker R, et al. Best practice treatment algorithm for primary open-angle glaucoma: implications for U.S. ophthalmology practice. Manag Care Interface. 2002:15(7):37-48.

9. Pelton JN. The future of telecommunications: a Delphi survey. J Commun. 1981;31 (1):177-89.

10. Goodman CM. Delphi technique: a critique. J Adv Nurs. 1987;12(6):729-34.
11. Pearson SD, Margolis CZ, Davis S, Schreier LK, Sokol HN, Gottlieb LK. Is consensus reproducible? A study of an algorithmic guidelines development process. Med Care. 1995;3(6):643-60

12. Fink A, Kosecoff J, Chassin M, Brook RH. Consensus methods: characteristics and guidelines for use. Am J Public Health. 1984;74(9):979-83.

13. Milholland AV, Wheller SJ, Heieck JJ. Medical assessment by Delphi group opinion technique. N Eng J Med. 1973;288(24):1272-5.

14. Bonini S, Bonini S, Lambiase A, Marchi S, Pasqualetti P, Zuccaro O, et al. Verna keratoconjunctivitis revisited: a case series of 195 patients with long-term followup. Ophthalmology. 2000;107(6):1157-63.

15. Hodges MG, Keane-Myers AM. Classification of ocular allergy. Curr Opin Allergy Clin Immunol. 2007;7(5):424-8.

16. BenEzra D. Classification of conjunctivitis and blepharitis. In BenEzraD, editor. Blepharitis and conjunctivitis: guidelines for diagnosis and treatment. Barcelona, Spain: Editoria Glosa; 2006.

17. Bonini S, Sacchetti M, Mantelli F, Lambiase A. Clinical grading of vernal keratoconjunctivitis. Curr Opin Allergy Clin Immunol. 2007;7(5):436-41

18. Calonge M, Herreras JM. Clinical grading of atopic keratoconjunctivitis. Curr Opin Allergy Clin Immunol. 2007;7(5):442-5.

19. Mantelli F, Santos MS, Petitti T, Sgrulletta R, Cortes M, Lambiase A, et al. Systematic review and meta-analysis of randomized clinical trials on topical treatments for vernal keratoconjunctivitis. Br J Ophthalmol. 2007;91(12):1656-61

20. Finegold I,Granet DB, D'Arienzo PA, Epstein AB. Efficacy and response with olopatadine versus epinastine in ocular allergic symptoms: a post hoc analysis of data from a conjunctival allergen challenge study. Clin Ther. 2006;28(10):1630-8.

21. Hingorani M, Moodaley L, Calder VL, Buckley RJ, Lightman S. A randomized, placebocontrolled trial of topical cyclosporine A in steroid dependent atopic keratoconjunctivitis. Ophthalmology. 1998;105(9):1715-20

22. Akpek EK, Dart JK, Watson S, Christen W, Dursun D, Yoo S, et al. A randomized trial of topical cyclosporin $0.05 \%$ in topical steroid-resistant atopic keratoconjunctivitis. Ophthalmology. 2004;111(3):476-82.

23. Tse DT, Mandelbaum S, Epstein E, Baerveldt G, Fein W. Mucous membrane grafting for severe palpebral vernal conjunctivitis. Arch Ophthalmol. 1983;101(12):1879-83.

24. Nishiwaki-Dantas MC, Dantas PEC, Pezzutti S, Finzi S. Surgical resection of giant papillae and autologous conjunctival graft in patients with severe vernal keratoconjunctivitis and giant papillae. Ophthalmic Plast Reconstr Surg. 2000;16(6):438-42. 